\title{
A modeling sensitivity study of the influence of the Atlantic meridional overturning circulation on neodymium isotopic composition at the Last Glacial Maximum
}

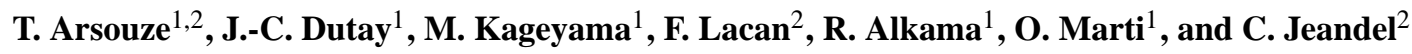 \\ ${ }^{1}$ Laboratoire des Sciences du Climat et de l'Environnement (LSCE), CEA/CNRS/UVSQ/IPSL, Orme des Merisiers, \\ Gif-Sur-Yvette, Bat 712, 91191 Gif sur Yvette cedex, France \\ ${ }^{2}$ Laboratoire d'Etudes en Géophysique et Océanographie Spatiale (LEGOS), CNES/CNRS/UPS/IRD, Observatoire \\ Midi-Pyrénées, 14 av. E. Belin, 31400 Toulouse, France
}

Received: 6 February 2008 - Published in Clim. Past Discuss.: 18 March 2008

Revised: 2 June 2008 - Accepted: 7 August 2008 - Published: 4 September 2008

\begin{abstract}
Using a simple parameterisation that resolves the first order global Nd isotopic composition (hereafter expressed as $\varepsilon_{\mathrm{Nd}}$ ) in an Ocean Global Circulation Model, we have tested the impact of different circulation scenarios on the $\varepsilon_{\mathrm{Nd}}$ in the Atlantic for the Last Glacial Maximum (LGM), relative to a modern control run. Three different LGM freshwater forcing experiments are performed to test for variability in the $\varepsilon_{\mathrm{Nd}}$ oceanic distribution as a function of ocean circulation. Highly distinct representations of the ocean circulation are generated in the three simulations, which drive significant differences in $\varepsilon_{\mathrm{Nd}}$, particularly in deep waters of the western part of the basin. However, at the LGM, the Atlantic is more radiogenic than in the modern control run, particularly in the Labrador basin and in the Southern Ocean. A fourth experiment shows that changes in $\mathrm{Nd}$ sources and bathymetry drive a shift in the $\varepsilon_{\mathrm{Nd}}$ signature of the basin that is sufficient to explain the changes in the $\varepsilon_{\mathrm{Nd}}$ signature of the northern end-member (NADW or GNAIW glacial equivalent) in our LGM simulations. All three of our LGM circulation scenarios show good agreement with the existing intermediate depth $\varepsilon_{\mathrm{Nd}}$ paleo-data. This study cannot indicate the likelihood of a given LGM oceanic circulation scenario, even if simulations with a prominent water mass of southern origin provide the most conclusive results. Instead, our modeling results highlight the need for more data from deep and bottom waters from western Atlantic, where the $\varepsilon_{\mathrm{Nd}}$ change in the three LGM scenarios is the most important (up to 3 $\left.\varepsilon_{\mathrm{Nd}}\right)$. This would also aid more precise conclusions concern-
\end{abstract}

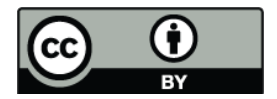

Correspondence to: J.-C. Dutay (dutay@1sce.ipsl.fr) ing the evolution of the northern end-member $\varepsilon_{\mathrm{Nd}}$ signature, and thus the potential use of $\varepsilon_{\mathrm{Nd}}$ as a tracer of past oceanic circulation.

\section{Introduction}

Ocean circulation plays an important role in climate change as it is suspected to be an amplifier, or even a trigger, of shifts between glacial and interglacial periods (Broecker and Denton, 1989; Charles and Fairbanks, 1992; Rahmstorf, 2002). The meridional circulation structure (Meridional Overturning Circulation - MOC) of the North Atlantic Basin plays a key role in transferring heat to the high latitudes of this basin. The southward transport of cold water at depth, as the North Atlantic Deep Water (NADW), towards the Antarctic circumpolar current is compensated by the northward transport of heat from the south in surface and thermocline waters. This Atlantic overturning cell is a dynamic element of the oceanic thermohaline circulation (THC) and acts on the atmospheric circulation and chemistry $\left(\mathrm{CO}_{2}\right.$ in particular), which are directly involved in governing climate. An ongoing problem for climatologists is to determine if the MOC will persist in the future and therefore to determine what controls its strength and variability. Studying different climate scenarios can assist in understanding the factors controlling the MOC and permits the evaluation of different forcings.

The climate during the Last Glacial Maximum (LGM) was drastically different to today and lasted a few millennia (from 23 to $19 \mathrm{ky} \mathrm{BP}$ ). Assessing how changes in the different components of the climate system (atmosphere, ice, land, and

Published by Copernicus Publications on behalf of the European Geosciences Union. 
in this present study, MOC) control the overall climate requires the determination of the distinct processes which result in different climatic conditions. However, understanding the behaviour of past oceanic circulation, water-mass composition and flow patterns, remains problematic due to the multiple factors that force the ocean system, as well as controlling the distribution of relevant paleo-proxies. Different geochemical and isotopic paleo-proxies often give contradictory results (Lynch-Stieglitz et al., 2007) and up to three possible MOC scenarios are considered at LGM:

1. A highly stratified basin with a water mass at a maximum depth of $2200 \mathrm{~m}$ (with characteristics comparable to modern NADW; often referred to as Glacial North Atlantic Intermediate Water, GNAIW), overlying a large volume of water that originates from the Antarctic (which can be viewed as a more northward version of modern Antarctic Bottom Water, AABW). This view was first suggested by cadmium to calcium ratios $(\mathrm{Cd} / \mathrm{Ca})$ and carbon isotopes $\left(\delta^{13} \mathrm{C}\right)$ preserved in the fossilised shells of benthic foraminifera, which are used as proxies of the paleo nutrient distribution (Marchitto and Broecker, 2006; Duplessy et al., 1988; Curry and Lohmann, 1983; Charles and Fairbanks, 1992). Measurements of radiocarbon $\left({ }^{14} \mathrm{C}\right)$ from benthic foraminifera suggest an older age for GNAIW at the LGM (Keigwin, 2004), which implies a slower circulation, with deep water ventilation times as great as 2000 years (compared to 500 years for Holocene, Keigwin and Schlegel, 2002).

2. On the other hand, carbon isotope data (Curry and Oppo, 2005) and $\mathrm{Cd} / \mathrm{Ca}$ data (Oppo and Rosenthal, 1994) has also suggested that vigorous overturning was maintained. Protactinium and thorium isotopes $(231 \mathrm{~Pa} / 230 \mathrm{Th})$ initially indicated that there was no significant change in the MOC at the LGM (Yu et al., 1996), while more recent data indicate a slowdown by almost $30 \%$ of the MOC associated with shorter residence times for waters in the Atlantic basin. This suggests that a shallower more vigorous overturning down to intermediate depths was associated with a weakened deep water ventilation (Marchal et al., 2000; McManus et al., 2004; Gherardi et al., 2005).

3. Oxygen isotopes $\left(\delta^{18} \mathrm{O}\right)$ from benthic foraminifera permit the reconstruction of water density at a given depth and suggest that during the LGM, the east-west $\delta^{18} \mathrm{O}$ gradient was at least reduced or even reversed at the LGM (Lynch-Stieglitz et al., 2006). These observations are consistent with a very weak GNAIW cell, contradicting the circulation scenarios that are based on the above mentioned other proxies (Lynch-Stieglitz et al., 1999). On the other hand, alternative $\mathrm{Cd} / \mathrm{Ca}$ data support a strong slowdown in the LGM MOC (Oppo and Fairbanks, 1987; Charles and Fairbanks, 1992; Broecker, 2002).

Each of these hypotheses have to be taken cautiously due to the scarcity of the data characterizing the LGM and the fact that the behaviour of these proxies in the past is not completely understood (Lynch-Stieglitz et al., 2007). Overall, there is currently no consensus on the structure of the LGM ocean circulation. Apart from the necessary acquisition of more field observations, a better knowledge of the processes forcing glacial circulation would be aided by the representation of different circulatory proxies in numerical models. This has motivated the recent modeling of proxies at LGM (Henderson et al., 1999; Marchal et al., 2000), in order to better constrain the processes that drive the observed variability in the temporal distribution of such proxies.

$\mathrm{Nd}$ isotopic composition (Nd IC, hereafter expressed as

$\varepsilon_{\mathrm{Nd}}=\left(\left(\mathrm{Nd}^{143} / \mathrm{Nd}^{144}\right)_{\text {sample }} /\left(\mathrm{Nd}^{143} / \mathrm{Nd}^{144}\right)_{\mathrm{CHUR}}-1\right) \times 10000$,

where CHUR is the CHondritic Uniform Reservoir, which represents the present day average value for the Earth surface, $\left(\mathrm{Nd}^{143} / \mathrm{Nd}^{144}\right)_{\text {CHUR }}=0.512638$; Jacobsen and Wasserburg, 1980), behaves quasi-conservatively in the open ocean, apart from any lithogenic inputs. Although surface scavenging and deep remineralization affects the $\mathrm{Nd}$ concentration profiles, $\varepsilon_{\mathrm{Nd}}$ data suggest that $\varepsilon_{\mathrm{Nd}}$ is relatively unaffected by biological cycles. Variations in $\varepsilon_{\mathrm{Nd}}$ have been measured in different water masses of the same water column, and this parameter has been used as a water mass tracer (Piepgras and Wasserburg, 1982; Jeandel, 1993; von Blanckenburg, 1999; Lacan and Jeandel, 2004; Amakawa et al., 2004; Goldstein and Hemming, 2003).

The modern Atlantic basin is characterized by two wellidentified end-members: specifically, a negative signature $\left(-13.5 \pm 0.5 \varepsilon_{\mathrm{Nd}}\right.$; Piepgras and Wasserburg, 1980, 1987; Lacan and Jeandel, 2005a) of NADW acquired in the Nordic and Labrador seas and a less negative signal from the southern water masses (AAIW and AABW, $\varepsilon_{\mathrm{Nd}}=-8 \pm 1$; Piepgras and Wasserburg, 1982; Jeandel, 1993) that originates from mixing of non radiogenic Atlantic waters and radiogenic $\mathrm{Pa}-$ cific waters. The evolution in $\varepsilon_{\mathrm{Nd}}$ along the modern day THC, from negative values in the north Atlantic, to positive values in the Pacific, makes $\varepsilon_{\mathrm{Nd}}$ a good candidate as a tracer of paleocirculation, and of the THC in particular. Planktonic or benthic foraminifera, benthic ferromanganese nodules and crusts, as well as iron-manganese oxides coatings are carrier phases that record the variations in $\varepsilon_{\mathrm{Nd}}$ from surface and bottom water mass signatures over different time scales (Elderfield et al., 1981; Vance and Burton, 1999; Albarede et al., 1997; Abouchami et al., 1999; Rutberg et al., 2000; Bayon et al., 2002; van De Flierdt et al., 2004; Piotrowski et al., 2004). For example, Piotrowski et al. (2004) measured the $\varepsilon_{\mathrm{Nd}}$ preserved in Fe-Mn oxides from LGM to mid Holocene in the South Atlantic, providing the first determination of circulation variations using $\mathrm{Nd}$ isotopic data at LGM. Nd 
oceanic cycle is far from being completely constrained and uncertainties remain concerning the ability of $\varepsilon_{\mathrm{Nd}}$ to trace paleo-circulation. Indeed, Piotrowski et al. (2004) assume no change in the $\varepsilon_{\mathrm{Nd}}$ in both North Atlantic and North Pacific end-members at the LGM. Accordingly, the temporal variations observed are interpreted as changes in circulation and the relative contribution of the two end members at the core site. However, Lacan and Jeandel (2005a) demonstrated that changes in water mass mixing during the formation of the northern water mass component could directly affect $\varepsilon_{\mathrm{Nd}}$ of this end-member. These authors further suggested that exchange of $\mathrm{Nd}$ between the sediment deposited on continental margins and the seawater occurred. This process, named "Boundary Exchange" (dissolved/particulates interaction along the continental margin, hereafter referred to as $\mathrm{BE}$ ), is highly likely to modify the signature of water masses flowing along these margins (Jeandel et al., 1998; Lacan and Jeandel, 2005b; Arsouze et al., 2007). Therefore, changes in the continental weathering regime, which will alter sediment fluxes and the type of material deposited along the continental margin, (Vance and Burton, 1999; Reynolds et al., 2004), are likely to affect the $\varepsilon_{\mathrm{Nd}}$ composition of the endmembers. Also, the shifts in the sites of deep water formation to lower latitudes (Ganopolski et al., 1998) may imply a change the nature of the material exchanged with seawater. Such processes may weaken the hypothesis that Nd endmember signatures are invariant in time and under different climatic conditions. Three recent studies focused on trying to identify if the northern end-member $\varepsilon_{\mathrm{Nd}}$ varied on glacialdeglacial time scales, based on the analysis of both deep sea corals (van de Flierdt et al., 2006) and ferromanganese crusts (Foster et al., 2007) or oxyhydroxide (Gutjahr et al., 2008) as carrier phases. Unfortunately, their results are still controversial, leaving the problem unresolved (cf. Sect. 5.3). We here suggest that modeling can bring a new perspective to the discussion.

In this study, we use a modeling approach to reconstruct the global scale distribution of $\varepsilon_{\mathrm{Nd}}$ at the LGM. Our aim is to investigate the extent to which the observed temporal variation in $\varepsilon_{\mathrm{Nd}}$ data reflects changes in either the MOC, the signatures of the two end-members, or some combination of the two. We therefore test the evolution of $\varepsilon_{\mathrm{Nd}}$ distribution under different representations of the LGM oceanic circulation generated by the IPSL (Institut Pierre-Simon Laplace) atmosphere-ocean coupled model. Firstly, the characteristics of this model and the dynamical features of the different simulations performed are described. We then present $\varepsilon_{\mathrm{Nd}}$ distributions for each run, in order to compare the changes in simulated circulation between LGM and modern state. Finally, we compare the output with the available data and evaluate the importance of the different processes that generate the LGM $\varepsilon_{\text {Nd }}$ distribution.

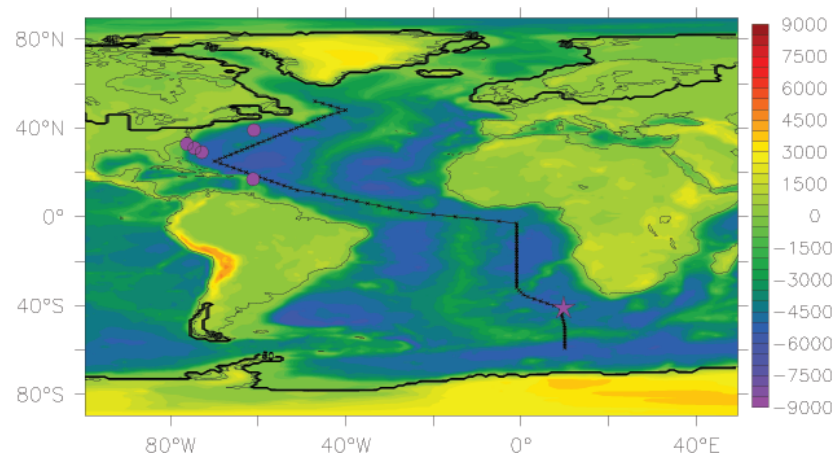

Fig. 1. Bathymetry and topography map at LGM, with modern continent contours. Sea level was $120 \mathrm{~m}$ lower at LGM than at Holocene (inducing larger Patagonian or New Foundland Plateau), with present oceanic regions covered by ice sheets (enclosed by thick line) over the Barent Sea, Hudson Bay or Nordic Sea, and the closure of the Bering Strait. The black line represents the trajectory of the vertical section in Figs. 3 and 4. LGM and glacial/interglacial core location are represented by purple star (Piotrowski et al., 2004) and circles (van de Flierdt et al., 2006; Foster et al., 2007; Gutjahr et al., 2008).

\section{Description of the numerical experiments}

All atmosphere-ocean simulations used in the present study are performed with the IPSL_CM4 model (Ocean Atmosphere Global Circulation Model - OAGCM) developed at Institut Pierre Simon Laplace (Marti et al., 2006). The individual modules of this coupled model are LMDz.3.3 (LMD, Hourdin et al., 2006) in a $3.75^{\circ} \times 2.5^{\circ}$ resolution for the atmosphere circulation, ORCHIDEE for the land surface (Krinner et al., 2005), the NEMO model in its coarse resolution version ORCA2, (LOCEAN, Madec, 2006) for the ocean, and the associated sea ice component is represented by the LIM model (developed at UCL-ASTR, Fichefet and Maqueda, 1997; Goosse and Fichefet, 1999). The three constituent parts of the OAGCM (ocean, atmosphere and sea ice) are coupled using the OASIS coupler (CERFACS, Valcke, 2006).

The control simulation (modern run, cf. Table 1 and Fig. 2) is the pre-industrial simulation run for the recent IPCC exercise (IPCC, 2007, http://ipcc-wg1.ucar.edu/wg1/wg1-report. $\mathrm{html})$. The MOC in this simulation is relatively weak $(\approx 10 \mathrm{~Sv})$ compared to the most recent evaluations (Swingedouw et al., 2007). This shortfall in the modern MOC is partly explained by the lack of convection in the Labrador Sea.

For the LGM simulations, the land-sea mask, topography and ice-sheet extent are prescribed according to the Peltier ICE-5G reconstruction (Peltier, 2004). Consequently, ice sheets cover Hudson Bay, the Baltic Sea, the Bering Strait and the Barents Sea and present shallow areas such as the Patagonian and New Foundland continental shelf become part of the adjacent continent (Fig. 1). All simulations 
use reduced atmospheric concentrations of $\mathrm{CO}_{2}, \mathrm{CH}_{4}$ and $\mathrm{N}_{2} \mathrm{O}$ to $185 \mathrm{ppm}, 350 \mathrm{ppb}$ and $200 \mathrm{ppb}$ respectively, and the 21 ky BP orbital parameters, according to the PMIP2 protocol (http://pmip2.lsce.ipsl.fr). Three runs are been performed that use a river routing scheme adapted for LGM conditions, i.e. addressing the impact of ice-sheets on river basins (Alkama et al., 2006; Alkama et al., 2008). In all three simulations, snow that accumulates on the ice-sheets is redistributed as a fresh water flux to the ocean so that the simulations have a closed fresh water budget. Three latitude bands are defined, with limits at $90^{\circ} \mathrm{S} / 50^{\circ} \mathrm{S} / 40^{\circ} \mathrm{N} / 90^{\circ} \mathrm{N}$. The $40^{\circ} \mathrm{N}$ limit corresponds to the southernmost latitudes reached by icebergs during ice ages. In each latitude band, the excess freshwater, which we define as calving, is integrated and supplied to the ocean in the same latitude band. For the northern band, freshwater fluxes due to calving are delivered to the Atlantic and Arctic Oceans, but not to the Pacific. In all three simulations, there is a remaining imbalance in the fresh water budget due to a slightly non conservative atmospheric convection scheme. In simulations LGMa and LGMb, the fresh water budget is closed using different methods. For LGMa, this bias is compensated for by multiplying global precipitation by $2.1 \%$. This simulation presents in a strong overturning in the Atlantic Ocean, reaching $18 \mathrm{~Sv}$, $8 \mathrm{~Sv}$ stronger than the control run). In LGMb, the calving flux is multiplied by $44 \%$. Both LGMa and LGMb have a closed fresh water balance. In LGMc, the calving flux has been multiplied by $100 \%$. The MOC slows down to only $6 \mathrm{~Sv}$. The additional freshwater added to the northern latitude band corresponds to $0.18,0.25$ and $0.35 \mathrm{~Sv}$ for LGMa, LGMb and LGMc, respectively (cf. Table 1).

Even though changes in fresh water forcing remain relatively small, they result in a variety of representations of the MOC. LGMb is generally similar to LGMa, where a dominant and vigorous water mass from the north fills the basin, but in contrast to LGMa, bottom water from the south enters to more northerly latitudes during LGMb. The MOC in LGMc can be viewed as a reproduction of one of the proposed LGM circulation scenarios (scenario 1), wherein the influence of southern component water is increased and the northern component water flows south at shallower depth than current NADW (thus corresponding to the GNAIW). In addition, we also performed a simulation with modern boundary conditions but retaining the LGM land-sea distribution. Because a change in sea-level and in the extent of icesheets induce a change in the definition of continental margin, and thus a change in Nd inputs, this simulation, hereafter referred as modernM, tests the sensitivity of the $\varepsilon_{\mathrm{Nd}}$ distribution to changes in land-sea distribution. We note that circulation changes induced by using LGM bathymetry are not significant. AABW is slightly weaker than during the control simulation $(\approx 3 \mathrm{~Sv}$ compared to $5 \mathrm{~Sv})$, but the main structures and characteristic depths are conserved.
All LGM scenarios of ocean circulation were generated at the "Laboratoire des Sciences du Climat et de l'Environnement" (LSCE). A summary of the simulation characteristics and the overturning sections are provided in Table 1 and Fig. 2.

\section{$3 \quad \varepsilon_{\mathrm{Nd}}$ modeling}

$\varepsilon_{\mathrm{Nd}}$ is simulated following the approach described in $\mathrm{Ar}-$ souze et al. (2007). The oceanic $\varepsilon_{\mathrm{Nd}}$ distribution is generated by a passive tracer model that solves the equation:

$\frac{\partial \varepsilon_{\mathrm{Nd}}}{\partial t}=S\left(\varepsilon_{\mathrm{Nd}}\right)-U \cdot \nabla \varepsilon_{\mathrm{Nd}}+\nabla \cdot\left(K \nabla \varepsilon_{\mathrm{Nd}}\right)$

where $S\left(\varepsilon_{\mathrm{Nd}}\right)$ is the Source-Sink term of the element, $U \cdot \nabla \varepsilon_{\mathrm{Nd}}$ and $\nabla \cdot\left(K \nabla \varepsilon_{\mathrm{Nd}}\right)$ are the three dimensional advective and diffusive terms, calculated with pre-computed advection $(U)$ and diffusion $(K)$ fields (off-line method) (Lévy et al., 2006).

The only source/sink term taken into account is BE, which is parameterized as a relaxing term towards the continental margin $\varepsilon_{\mathrm{Nd}}$ value:

$S\left(\varepsilon_{\mathrm{Nd}}\right)=1 / \tau \cdot\left(\varepsilon_{N d_{\text {mar }}}-\varepsilon_{\mathrm{Nd}}\right) \cdot$ mask $_{\mathrm{mar}}$

where $\tau$ is the relaxing time, $\varepsilon_{\mathrm{Nd}_{\mathrm{mar}}}$ is the $\varepsilon_{\mathrm{Nd}}$ value of the continental margin, $\varepsilon_{\mathrm{Nd}}$ is the prognostic variable for Nd IC of seawater in the model, and mask $\mathrm{mar}_{\text {is }}$ a fraction of margin in a numerical grid box.

The relaxing time is set to vary from six months in surface waters to 10 years at $3000 \mathrm{~m}$ depth. We have not attempted to account for geographical variations of this profile because it remains a difficult task to parameterize spatial variability, when one considers the current knowledge of the factors acting on BE (e.g. nature of the sediment on the margin, overlying currents, bathymetry, etc...). The parameters chosen for the vertical profiles provide the best results for the modern ocean (Arsouze et al., 2007). This parameterization of BE implies that the short relaxing time at the surface will result in a strong exchange between the water mass and the continental margin, while a longer relaxing time at the at depth results in a weaker exchange between the water mass and the continental margin. We refer to Arsouze et al. (2007) for a more detailed description of this parameterisation used for $\varepsilon_{\mathrm{Nd}}$ modeling.

Since the decay of the radioactive isotope ${ }^{147} \mathrm{Sm}$ to ${ }^{143} \mathrm{Nd}$ takes much longer (a half life of $106 \mathrm{~Gy}$ ) than the studied time interval (about 20ky), we assumed there to be no evolution of the isotopic signature of the margin due to natural radioactive decay between LGM and Holocene. In addition, because no major tectonic reorganizations have occurred since the LGM, the overall margin $\varepsilon_{\mathrm{Nd}}$ distribution was likely very similar to that of today. Therefore, we apply the margin $\varepsilon_{\mathrm{Nd}}$ composition established by Jeandel et al. (2007) for our LGM simulations. Finally, we assume the 


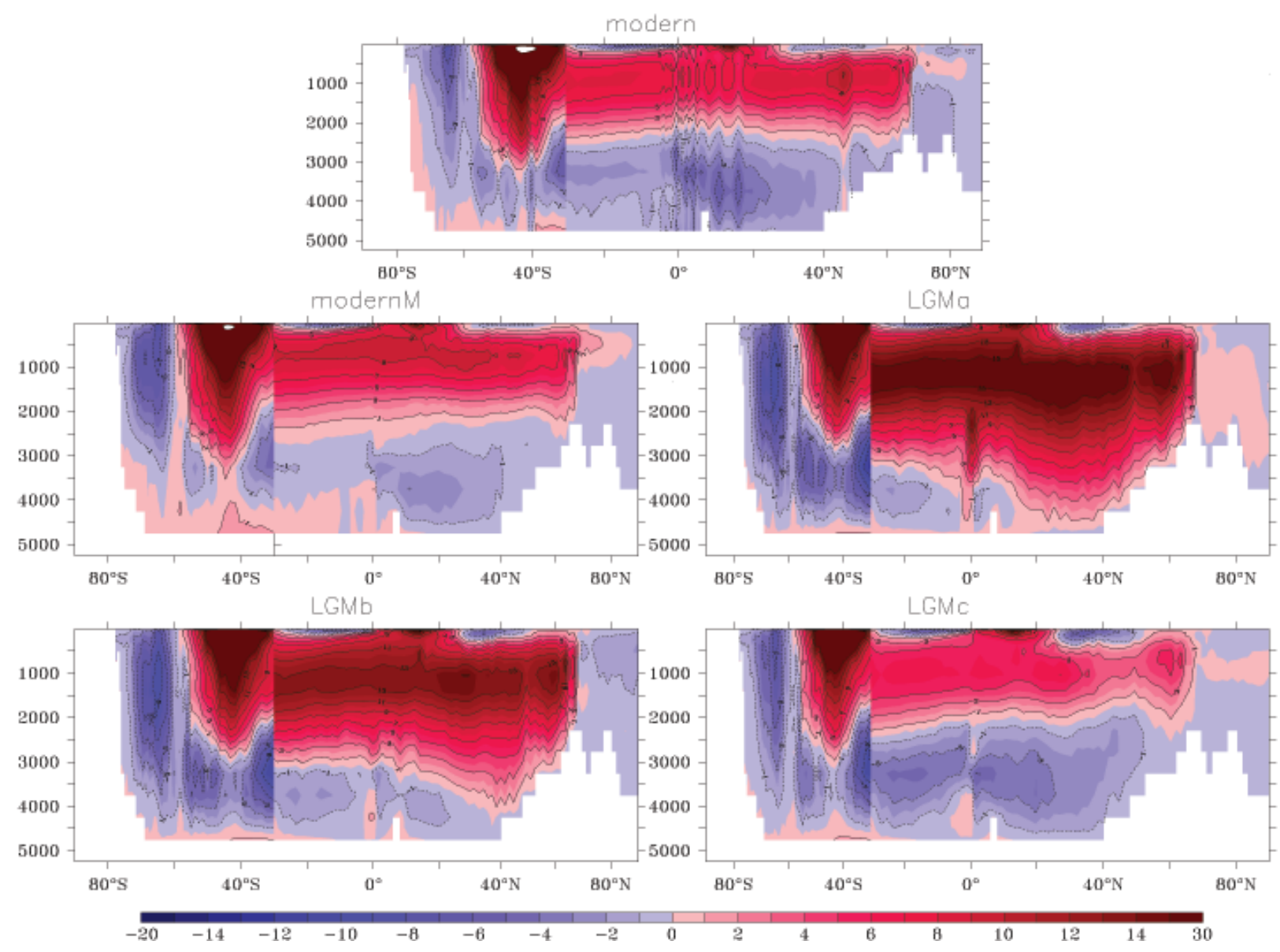

Fig. 2. Meridional overturning streamfunction (in Sv) of the Atlantic basin, north of $30^{\circ} \mathrm{S}$, and of global ocean south of $30^{\circ} \mathrm{S}$, for all simulations. The vertical line break at $30^{\circ} \mathrm{S}$ is produced by this change in streamfunction visualisation. modernM simulation produces a circulation somewhat similar to the control run. LGMa, and to a lesser extent LGMb, simulations are characterized by a strong and dominant water mass from the north that fills the basin. However, water masses that originate from the south enter in the basin at northern latitudes in LGMb, which is not the case in LGMa. On the contrary, in LGMc simulation, the influence of southern component water is increased and fulfils the basin at depth, while the northern component water flows south at shallower depth than current NADW.

vertical parameterisation and relaxing time, that characterizes BE, to be unchanged at the LGM. This last hypothesis has to be taken cautiously, because terrigenous fluxes were possibly higher at the LGM (Franzese et al., 2006). However, until the impact of these fluxes on BE can be better constrained, we base our hypothesis on Tachikawa et al.'s results (2003), which found a minor impact of terrigenous flux variations on the $\varepsilon_{\mathrm{Nd}}$ signatures of deep water masses.

We acknowledge that this simplistic modeling parameterization can only resolve the first order representation of the oceanic $\varepsilon_{\mathrm{Nd}}$ distribution. Therefore, our ability to determine to which extent changes in circulation drive changes in the $\varepsilon_{\mathrm{Nd}}$ of end-members is limited by the accuracy of our parameterization of the $\varepsilon_{\mathrm{Nd}}$ oceanic cycle. In fact, Arsouze et al. (2007) have shown that despite a correct representation of the $\varepsilon_{\mathrm{Nd}}$ composition of the major ocean water masses of the inter oceanic basin gradient, the modeled values in the At- lantic are still slightly too radiogenic compared to the available data (Figs. 3 and 5 in Arsouze et al., 2007). In this study, our main objective resides in studying the response of the model to a change in circulation and inputs (in term of $\varepsilon_{\mathrm{Nd}}$ gradient). Our modeling efforts must be seen as a first step towards reproducing the absolute value of the data provided by paleoceanographers (Piotrowski et al., 2004; Gutjahr et al., 2008). The proposed model must therefore be understood as a tool to further investigate the $\varepsilon_{\mathrm{Nd}}$ distribution and the end-member signatures in the Atlantic under LGM forcing.

\section{Results}

A section chosen to fit the classical western basin section in the northern part of the Atlantic, and to compare with the available data in the south (Figs. 3 and 4), as well as a map of 
Table 1. Main characteristics of the simulations. $\varepsilon_{\mathrm{Nd}}\left(\right.$ Holocene), $\varepsilon_{\mathrm{Nd}}(\mathrm{LGM})$ and $\Delta \varepsilon_{\mathrm{Nd}}$ are data values. Modern run is the reference run obtained with pre-industrial run forcings. Simulations LGMA, LGMB and LGMC are all produced with LGM forcings and boundary conditions (orbital parameters, ice sheets coverage and subsequent sea ice level drop, realistic river routing, atmosphere chemistry composition). The three LGM simulations are obtained with different calving fluxes (treatment of snow accumulating on the northern mid latitude ice sheets, which excess is redistributed over the ocean to close the freshwater budget). modernM simulation is obtained with modern forcing and LGM land-sea mask.

\begin{tabular}{|c|c|c|c|c|c|c|}
\hline $\begin{array}{l}\text { Experiment } \\
\text { Name }\end{array}$ & $\begin{array}{l}\text { Calving (fresh- } \\
\text { water from ice } \\
\text { sheets melt redis- } \\
\text { tributed north of } \\
40^{\circ} \mathrm{N} \text { ) }\end{array}$ & $\begin{array}{l}\text { North } \\
\text { component } \\
\text { water flow }\end{array}$ & $\begin{array}{l}\text { South } \\
\text { component } \\
\text { water flow }\end{array}$ & $\begin{array}{l}\text { Mean } \varepsilon_{\mathrm{Nd}} \text { of the } \\
\text { basin }\end{array}$ & $\begin{array}{l}\varepsilon_{\mathrm{Nd}} \text { of the south } \\
\text { component water } \\
\text { mass }\left(50^{\circ} \mathrm{S},\right. \\
\left.30^{\circ} \mathrm{W}\right) 4000 \mathrm{~m}\end{array}$ & $\begin{array}{l}\varepsilon_{\mathrm{Nd}} \text { of the norh } \\
\text { component water } \\
\text { mass }\left(50^{\circ} \mathrm{N},\right. \\
\left.50^{\circ} \mathrm{W}\right) 2500 \mathrm{~m}\end{array}$ \\
\hline Modern & - & $10 \mathrm{~Sv}$ & $5 \mathrm{~Sv}$ & -9.1 & -7.1 & -12.5 \\
\hline ModernM & - & $9 \mathrm{~Sv}$ & $3 \mathrm{~Sv}$ & -8.7 & -6.9 & -11.5 \\
\hline LGMa & $0.18 \mathrm{~Sv}$ & $18 \mathrm{~Sv}$ & $1 \mathrm{~Sv}$ & -8.6 & -6.5 & -10.3 \\
\hline LGMb & $0.25 \mathrm{~Sv}$ & $14 \mathrm{~Sv}$ & $2 \mathrm{~Sv}$ & -8.7 & -6.6 & -10.2 \\
\hline LGMc & $0.35 \mathrm{~Sv}$ & $6 \mathrm{~Sv}$ & $4 \mathrm{~Sv}$ & -8.7 & -6.7 & -10.5 \\
\hline $\begin{array}{l}\text { Experiment } \\
\text { Name }\end{array}$ & $\begin{array}{l}\varepsilon_{\mathrm{Nd}}, 41^{\circ} \mathrm{S}, \\
4500 \mathrm{~m} \\
\varepsilon_{\mathrm{Nd}}(\text { Holocene }) \\
=-9.4 \\
\varepsilon_{\mathrm{Nd}}(\mathrm{LGM}) \\
=-6.5\end{array}$ & $\begin{array}{l}\varepsilon_{\mathrm{Nd}}, 30^{\circ} \mathrm{N}, \\
4500 \mathrm{~m} \\
\varepsilon_{\mathrm{Nd}}(\text { Holocene }) \\
=-13.6 \\
\varepsilon_{\mathrm{Nd}}(\mathrm{LGM}) \\
=-10.3\end{array}$ & $\begin{array}{l}\varepsilon_{\mathrm{Nd}}, 30^{\circ} \mathrm{N}, \\
2000 \mathrm{~m} \\
\varepsilon_{\mathrm{Nd}}(\text { Holocene }) \\
=-13.5 \\
\varepsilon_{\mathrm{Nd}}(\mathrm{LGM}) \\
=-9.7\end{array}$ & $\begin{array}{l}\Delta \varepsilon_{\mathrm{Nd}}(\mathrm{LGM}- \\
\mathrm{Hol}) 41^{\circ} \mathrm{S} \\
4500 \mathrm{~m} \\
\Delta \varepsilon_{\mathrm{Nd}}(\text { data })= \\
+2.9\end{array}$ & $\begin{array}{l}\Delta \varepsilon_{\mathrm{Nd}}(\mathrm{LGM}- \\
\mathrm{Hol}) 30^{\circ} \mathrm{N} \\
4500 \mathrm{~m} \\
\Delta \varepsilon_{\mathrm{Nd}}(\text { data })= \\
+3.3\end{array}$ & $\begin{array}{l}\Delta \varepsilon_{\mathrm{Nd}}(\mathrm{LGM}- \\
\mathrm{Hol}) 30^{\circ} \mathrm{N} \\
2000 \mathrm{~m} \\
\Delta \varepsilon_{\mathrm{Nd}}(\text { data })= \\
+3.8\end{array}$ \\
\hline Modern & -7.6 & -7.8 & -10.9 & - & - & - \\
\hline ModernM & -7.5 & -7.8 & -10.1 & +0.2 & +0.1 & +0.7 \\
\hline LGMa & -7.1 & -9.8 & -8.8 & +0.4 & -1.9 & +2.1 \\
\hline LGMb & -7.0 & -8.8 & -9.4 & +0.6 & -1.0 & +1.5 \\
\hline LGMc & -7.0 & -7.6 & -9.7 & +0.5 & +0.3 & +1.2 \\
\hline
\end{tabular}

the $\varepsilon_{\mathrm{Nd}}$ difference between control and other simulations between 3000 and $5000 \mathrm{~m}$ depths (Fig. 5) are used to assess the $\varepsilon_{\mathrm{Nd}}$ distributions in the simulations and to compare them with the data provided by Piotrowski et al. (2004) and Gutjahr et al. (2008). Additionally, mean $\varepsilon_{\mathrm{Nd}}$ value of the basin and characteristic values of both south and north end-members are used to determine the respective influence of changes in $\mathrm{Nd}$ inputs and circulation variations (Table 1).

\subsection{Modern simulations}

\subsubsection{Control simulation}

The modern simulation produces a $\varepsilon_{\mathrm{Nd}}$ distribution that is in broad agreement with the existing data, with a $\varepsilon_{\mathrm{Nd}}$ composition of -12.5 and -7 for NADW and AABW, respectively (compare to the data values of -13.5 for NADW and -8 and AABW, Table 1, Figs. 3 and 4). Most modeled values fall within $3 \varepsilon_{\mathrm{Nd}}$ units of the observed values, even if some important discrepancies are observed. These are mainly in surface and sub-surface waters (above $1000 \mathrm{~m}$ ), due to the overestimated influence of radiogenic inputs along the ScotlandIceland-Greenland rise (Fig. 3). Also, as far north as $40^{\circ} \mathrm{N}$, unrealistic radiogenic southern waters are observed with val- ues of $-7.5 \varepsilon_{\mathrm{Nd}}$ (Fig. 3). The main structure of the $\varepsilon_{\mathrm{Nd}}$ distribution and its relationship to the main water masses filling the Atlantic basin are however reproduced.

The simulation of realistic first order $\varepsilon_{\mathrm{Nd}}$ gradients and water masses characteristics in the Atlantic Ocean therefore make the model a tool to consider using it for investigating the impact of the past variations in ocean circulation.

\subsection{2 modernM simulation}

modernM yields a more radiogenic mean $\varepsilon_{\mathrm{Nd}}$ distribution than for the control run $\left(+0.4 \varepsilon_{\mathrm{Nd}}\right.$; Table 1). The largest anomalies are observed in surface waters and at depth for the formation site of the northern end-member $(+1$; Figs. 4 and 5 ). This anomaly is subsequently propagated southward via the deep western boundary current. The $\varepsilon_{\mathrm{Nd}}$ composition of the Atlantic sector of the Southern Ocean remains virtually unaffected by bathymetry and land-sea mask changes (about $0.2 \varepsilon_{\mathrm{Nd}}$ more radiogenic).

\subsection{LGM simulations}

The three LGM simulations produce a $\varepsilon_{\mathrm{Nd}}$ distribution that is somewhat similar to the modern distribution with very radiogenic surface and bottom waters at all latitudes, and 

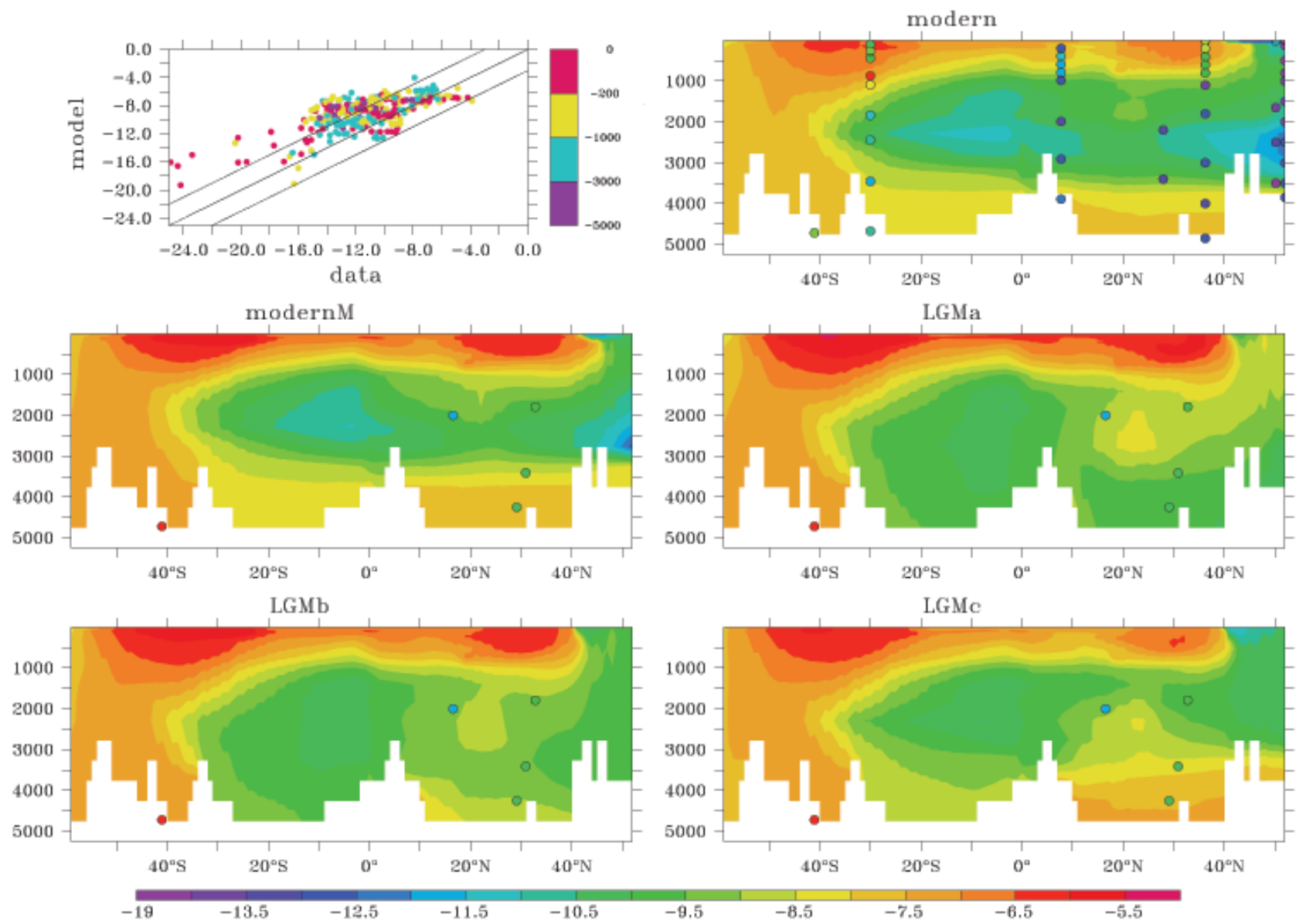

Fig. 3. Top left panel represents modeled $\varepsilon_{\mathrm{Nd}}$ versus measured $\varepsilon_{\mathrm{Nd}}$ over the Atlantic basin for reference modern simulation, as function of depth (colour code). Diagonal lines are lines of $\varepsilon_{\mathrm{Nd}}($ modeled $)=\varepsilon_{\mathrm{Nd}}($ data $), \varepsilon_{\mathrm{Nd}}($ modeled $)=\varepsilon_{\mathrm{Nd}}($ data $)+3 \varepsilon_{\mathrm{Nd}}$ and $\varepsilon_{\mathrm{Nd}}($ modeled $)=\varepsilon_{\mathrm{Nd}}($ data $)-$ $3 \varepsilon_{\mathrm{Nd}}$. Other panels are vertical $\varepsilon_{N d}$ sections along the track represented in black in Fig. 1 for all simulations. Data are superimposed in circles with the same colour code as simulation output. Data are provided by (Lacan and Jeandel, 2005a; Piepgras and Wasserburg, 1987; 1983; Spivack and Wasserburg, 1988; Jeandel, 1993) for modern control run (Foster et al., 2007; Gutjahr et al., 2008; Piotrowski et al., 2004) for LGM runs. The color scale is non linear. Reproduction of $\varepsilon_{\mathrm{Nd}}$ distribution in the modern control run is in correct agreement with the observation. LGM simulations generate highly distinct $\varepsilon_{\mathrm{Nd}}$ distribution, particularly at bottom depths.

intermediate waters with high $\varepsilon_{\mathrm{Nd}}$ values in the southern ocean. In the North, sandwiched between the surface and bottom water masses, there is a more negative $\varepsilon_{\mathrm{Nd}}$ deep water mass. The northern end-member $\varepsilon_{\mathrm{Nd}}$ values are however significantly different from the control (from -10.2 to -10.5 $\varepsilon_{\mathrm{Nd}}$ compared to $-12.5 \varepsilon_{\mathrm{Nd}}$ for control run, Table 1, Fig. 3). Despite significant changes in ocean circulation in our scenarios, the global mean $\varepsilon_{\mathrm{Nd}}$ during the LGM for the three sensitivity tests simulated $\varepsilon_{\mathrm{Nd}}$ in the Atlantic basin is unaffected by circulation changes and is $0.5 \varepsilon_{\mathrm{Nd}}$ more radiogenic than the modern scenario (Table 1). However, some remarkable changes are observed for different water masses.

\subsubsection{LGMa}

The MOC in LGMa is so vigorous that it propagates the positive signature from southern surface and intermediate wa- ters to northerly latitudes ( $+1.5 \varepsilon_{\mathrm{Nd}}$, Fig. 4) and further influences the signature of the northern end-member at depth $\left(2.2 \varepsilon_{\mathrm{Nd}}\right.$ more radiogenic than for the control simulation at $50 \circ \mathrm{N}$, Table 1). Even further south $\left(20^{\circ} \mathrm{S}\right)$, this northern end-member still remains more radiogenic (Fig. 4). The $\varepsilon_{\mathrm{Nd}}$ composition of the bottom water mass in all LGM simulations is directly related to the relative influence of the northern and southern end-members. Consequently LGMa, which is characterized by a deep and robust NADW cell, has the lowest $\varepsilon_{\mathrm{Nd}}$ among the three LGM simulations (Fig. 3). Finally, the isotopic composition for the Atlantic sector of the Southern Ocean (south of $30^{\circ} \mathrm{S}$ ) is also more radiogenic (up to $+0.7 \varepsilon_{\mathrm{Nd}}$, Fig. 5) relative to the modern control run. This is due to an increased influence of the more radiogenic south Pacific water masses, since LGMa is typified by a vigorous Antarctic Circumpolar Current (ACC). 

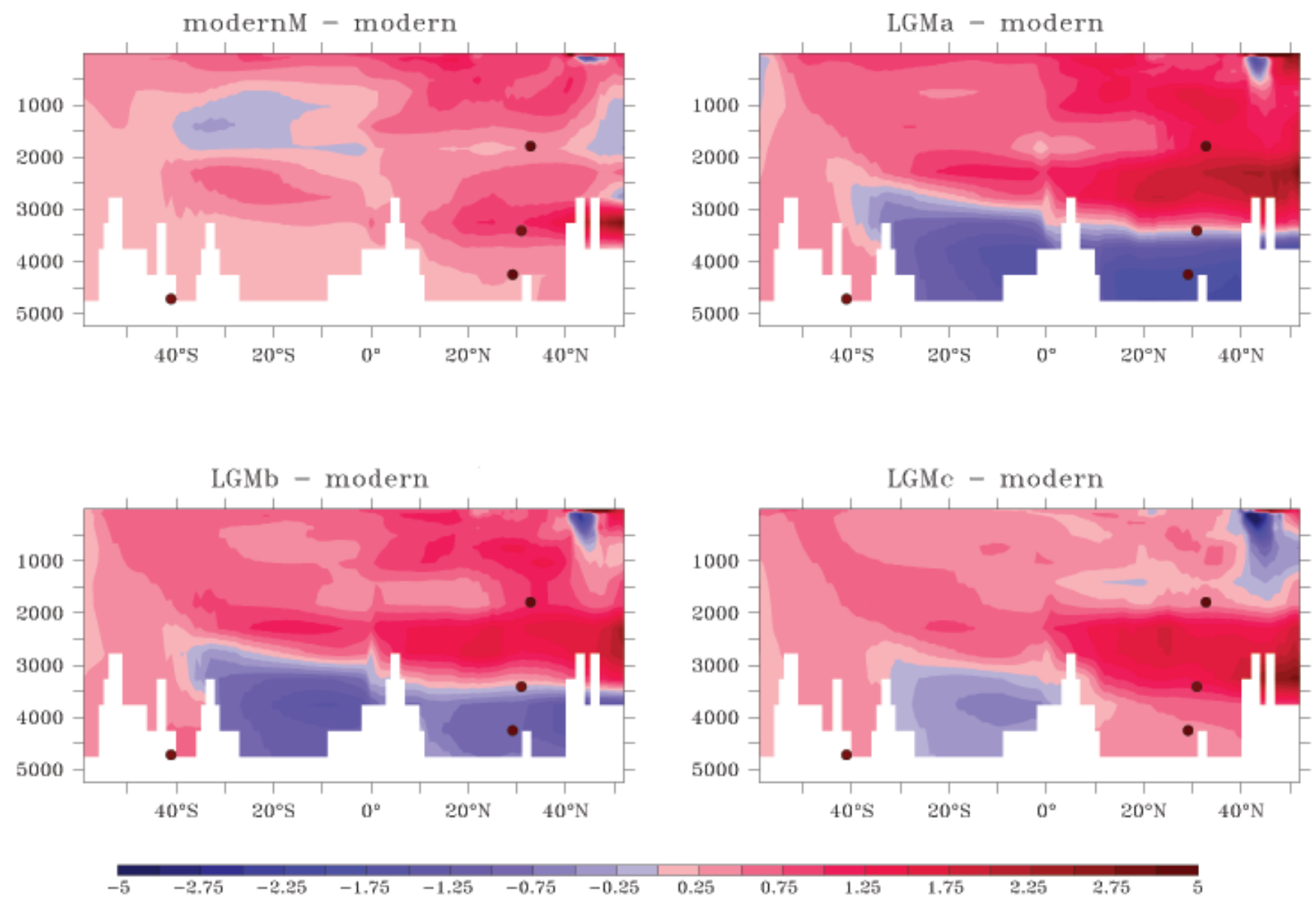

Fig. 4. Vertical $\varepsilon_{\mathrm{Nd}}$ variations along the track represented in black in Fig. 1 between reference modern run and modernM, LGMA, LGMB and LGMC simulations. Data is superimposed in circles with the same colour code as simulation output. LGM data is provided by (Foster et al., 2007; Gutjahr et al., 2008; Piotrowski et al., 2004). The color scale is non linear. LGMc simulation reproduces a correct tendency at all depths when compared with the available observations. Also, LGMa, with a strong circulation cell, reproduces a correct LGM-modern variation at $2000 \mathrm{~m}, 30^{\circ} \mathrm{N}$

\subsubsection{LGMb}

The LGMb simulation displays $\varepsilon_{\mathrm{Nd}}$ distribution similar to that of LGMa. However, the influence of the southern component is greater compared to the LGMa simulation, consistent with the dynamical properties of the simulation. Accordingly, the northern end-member is slightly more radiogenic $\left(\varepsilon_{\mathrm{Nd}}=-10.2\right)$ than during LGMa, but still influences the bottom water composition $\left(\varepsilon_{\mathrm{Nd}}=-8.8\right.$ compared to $\varepsilon_{\mathrm{Nd}}=-9.8$ for LGMa and $\varepsilon_{\mathrm{Nd}}=-7.8$ for the control simulation, Fig. 3). As for LGMa, the Atlantic sector of the Southern Ocean is influenced by radiogenic waters from the Pacific (Fig. 5).

\subsubsection{LGMc}

The northern end-member has a $\varepsilon_{\mathrm{Nd}}$ value of -10.5 which is slightly higher than our other LGM runs. However, LGMc presents a more dominant radiogenic AABW throughout the basin and consequently produces the highest $\varepsilon_{\mathrm{Nd}}$ bottom values $\left(\varepsilon_{\mathrm{Nd}} \approx-7\right.$, Fig. 3$)$. Unsurprisingly, LGMc, which represents the weakest LGM simulated ACC circulation, shows a more moderate influence of radiogenic waters from $\mathrm{Pa}$ cific (Fig. 5). Also, LGMc simulates large differences in $\varepsilon_{\mathrm{Nd}}$ between the western and eastern parts of the Atlantic basin (Fig. 5). As AABW preferentially flows in the western part of the Atlantic basin, the negative $\varepsilon_{\mathrm{Nd}}$ signature of GNAIW for LGMc is reflected only in the eastern part. This east west gradient in $\varepsilon_{\mathrm{Nd}}$ is not observed in the other LGM simulations, due to the predominant influence of northern water masses across the entire Atlantic basin. 

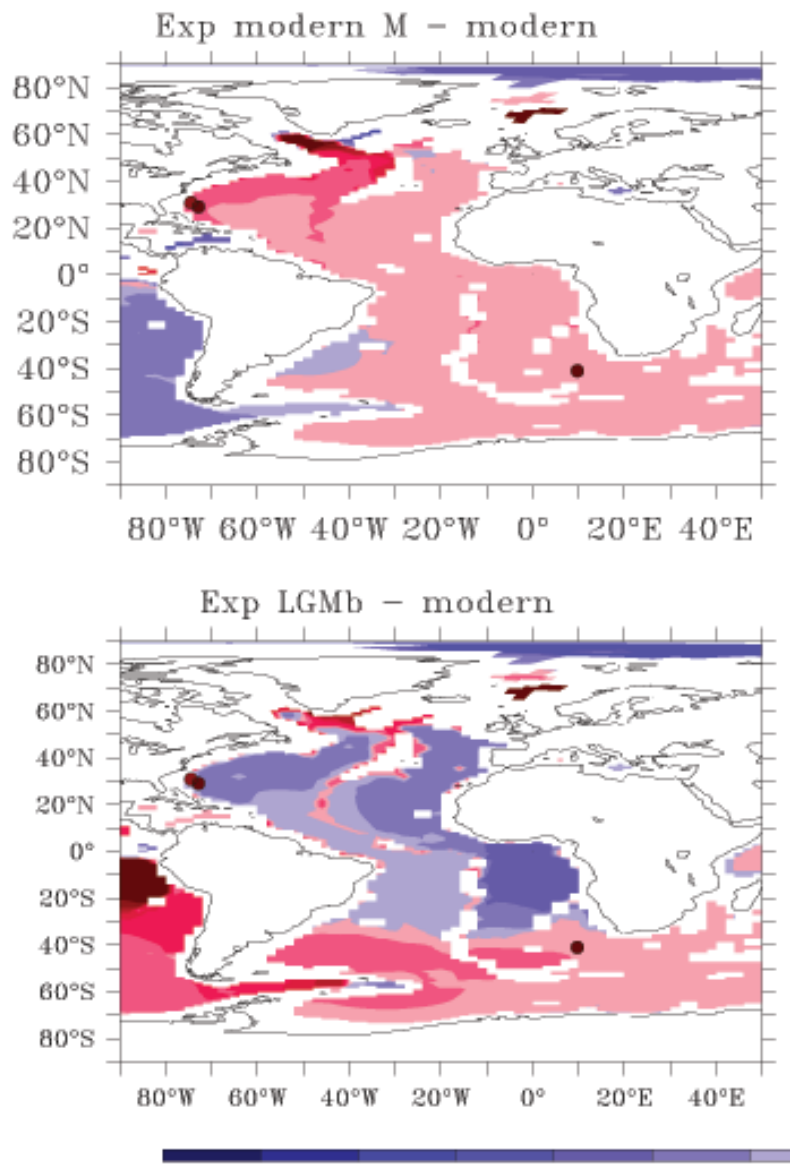
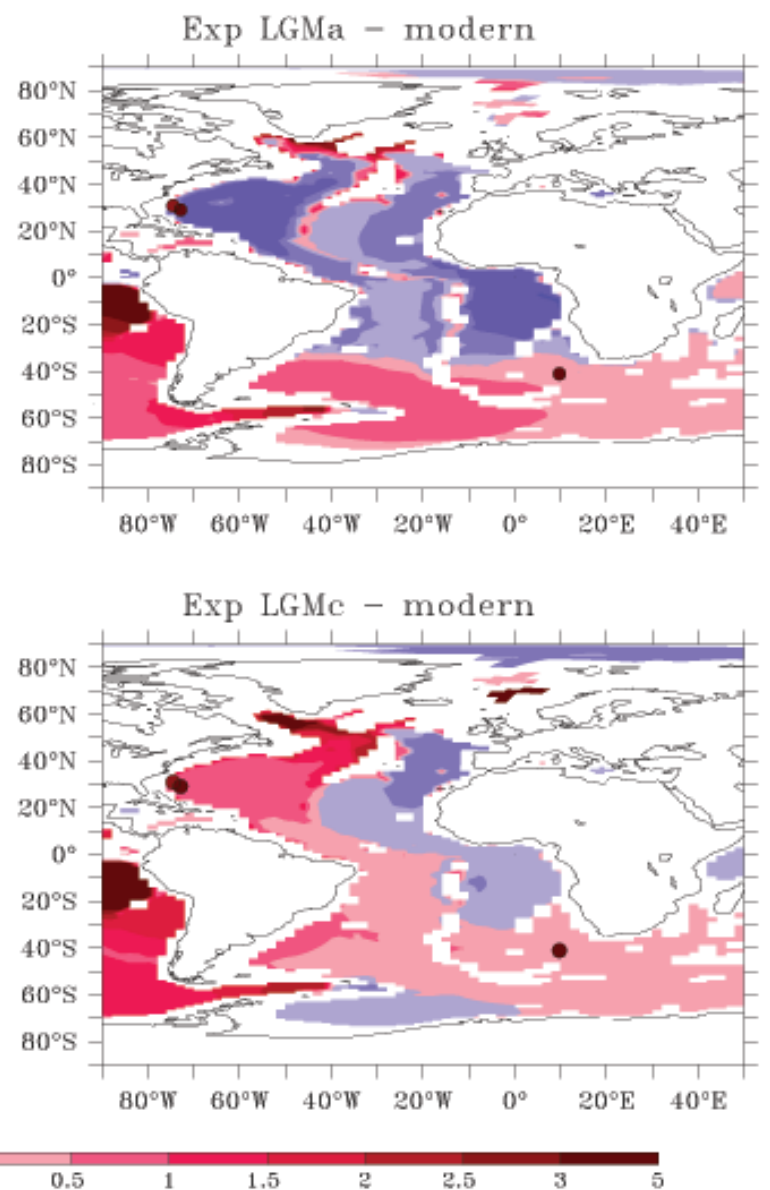

Fig. 5. Map of $\varepsilon_{\mathrm{Nd}}$ difference between reference run (modern run) and the four other runs (modernM, LGMA, LGMB, LGMC), averaged between 3000 and $5000 \mathrm{~m}$. Data are superimposed in circles with the same colour code as simulation output. LGM data are provided by (Foster et al., 2007; Gutjahr et al., 2008; Piotrowski et al., 2004). The color scale is non linear. LGMc is the only simulation that succeeds in reproducing a positive gradient in the western part of the basin.

\section{Discussion}

The simulated $\varepsilon_{\mathrm{Nd}}$ never differs by more than \pm 3.2 units between the three LGM simulations. In addition, when $\varepsilon_{\mathrm{Nd}}$ is averaged over the whole basin, the resulting difference between each set of two simulations never exceeds $+0.1 \varepsilon_{\mathrm{Nd}}$ (Table 1). Thus, the overall isotopic composition of the basin is not drastically influenced by the different circulation schemes with our parameterization scheme. However, circulation redistributes $\varepsilon_{\mathrm{Nd}}$ properties in different ways.

\subsection{Changes induced by bathymetry}

Firstly, the isotopic composition of the whole Atlantic basin is $+0.4 \varepsilon_{\mathrm{Nd}}$ more radiogenic for modernM simulation than for the control run. This demonstrates that the $\varepsilon_{\mathrm{Nd}}$ is likely affected by changes in bathymetry and the subsequent changes in Nd sources. This is due to the presence of ice sheets over the Barents Sea, Hudson Bay and even the Baltic $\mathrm{Sea}$, that prevent $\mathrm{BE}$ and reduce contact with very nega- tive $\varepsilon_{\mathrm{Nd}}$ margins (respectively $-15,-25$ and -18 , Jeandel et al., 2007). The closure of the Bering Strait, which prevents radiogenic waters from the North Pacific from entering the Arctic basin, appears to play a negligible role since the flux involved is important locally only. LGM topography and the presence of northern ice sheets induce variability in the exchange of $\mathrm{Nd}$ between water masses and continental margins and therefore drive a change in the $\varepsilon_{\mathrm{Nd}}$ of the northern end-member. In contrast, the southern end-member remains virtually insensitive to any change in bathymetry (less than $+0.2 \varepsilon_{\mathrm{Nd}}$ variation, during simulation modernM), while the three LGM scenarios result in AABW that is up to 0.7 $\varepsilon_{\mathrm{Nd}}$ more radiogenic (Table 1, Figs. 3 and 5). This difference might be explained by changes in circulation, such as the ACC strength, which mixes both the Atlantic and the more radiogenic Indo-Pacific waters to compose the southern end-member signature, as suggested by previous works (Duplessy et al., 1988; Charles and Fairbanks, 1992; Oppo and Rosenthal, 1994). 


\subsection{Comparison with data in South Atlantic}

The measured $\varepsilon_{\mathrm{Nd}}$ gradient between modern and LGM in the data provided by Piotrowski et al. (2004) $\left(+3 \varepsilon_{\mathrm{Nd}}\right)$ is not fully reproduced by any of our three LGM simulations (only $+1 \varepsilon_{\mathrm{Nd}}$ at maximum, Fig. 4), despite a good matching of the absolute LGM value of -6.5 . The simulation of the correct trend in $\varepsilon_{\mathrm{Nd}}$ between modern and LGM is encouraging, although the amplitude of the variation remains too low. This deficiency may be ascribed to either 1) the forcing term which may not be adapted to the area, or 2) the poor model resolution, which is therefore unable to reproduce all the processes of AABW propagation and formation along the Antarctic margin. This means the model falls short in characterizing the $\varepsilon_{\mathrm{Nd}}$ composition of AABW and is a classical problem of coarse resolution OGCMs (Dutay et al., 2002).

Geographically speaking, the location of the core studied by Piotrowski et al. (2004) is situated in an area of rough topography, which is not accurately reproduced in this coarse model. In addition, in our model this region is also influenced by a variety of factors aside from the relative influence of AABW and GNAIW. For example, ACC strength and associated sediment transport with a Pacific radiogenic signature, variation in Indo-Pacific radiogenic waters entering the basin via the Agulhas current are crudely resolved in our model (Franzese et al., 2006). This might influence the reproduction of $\varepsilon_{\mathrm{Nd}}$ either in a radiogenic or non radiogenic way, but makes the contribution of each factor unclear.

\subsection{Constraining $\varepsilon_{\mathrm{Nd}}$ north end-member evolution}

The critical problem in evaluating the potential of $\varepsilon_{\mathrm{Nd}}$ as a water mass tracer is to constrain the time-evolution of the isotopic composition of the end-members. Resolving this would also provide complementary information if used together with other chemical and isotopic paleotracers. The present study clearly suggests a difference of at least +0.5 $\varepsilon_{\mathrm{Nd}}$ for the northern end-member as compared to present.

However, van de Flierdt et al. (2006) measured Nd variations in deep-sea corals from the New England Seamounts during Younger Dryas (short time period at 11.5-12.9 kyr B.P. which is suspected to display an oceanic circulation regime similar to the LGM, Keigwin and Schlegel, 2002; Keigwin, 2004) and found signatures in $\varepsilon_{\mathrm{Nd}}$ of surface $\left(-14.5 \varepsilon_{\mathrm{Nd}}\right)$ and deep $\left(-13 /-13.5 \varepsilon_{\mathrm{Nd}}\right)$ waters that are similar to the present. They therefore concluded that there was probably no variation in the composition of end-members with time. Foster et al. (2007), using data in ferromanganese crusts over glacial/interglacial periods, also concluded that there was no significant change in the $\varepsilon_{\mathrm{Nd}}$ of north endmember, but the time resolution of their study ( $30 \mathrm{k} . \mathrm{y}$. at least) may be too low to constrain such short-term variations as those which characterize the LGM.

These two results provide an indication that the $\varepsilon_{\mathrm{Nd}}$ signature of the northern end-member is invariant through time.
In contrast, recent $\mathrm{Nd}$ data obtained in the authigenic $\mathrm{Fe}-\mathrm{Mn}$ oxyhydroxide fraction of sediments collected in the western boundary current shows that GNAIW at LGM displayed $\varepsilon_{\mathrm{Nd}}$ values that were 3.5 units greater, relative to the Holocene ones (Gutjahr et al., 2008). At the core location of Gutjahr et al. (2008), all three of our LGM simulations reproduce a northern end-member that is shifted to more radiogenic values at intermediate depths, with LGMa providing the most realistic results. These radiogenic values for LGMa are generated by strong overturning that transports surface radiogenic waters up to the formation site of the northern end-member.

Conversely, LGMc is the only simulation that succeeds in producing a correct tendency in $\varepsilon_{\mathrm{Nd}}$ LGM-Holocene variation for deep waters (i.e. a positive gradient, Table 1, Figs. 4 and 5). The glacial reduction in $\varepsilon_{\mathrm{Nd}}$ during this simulation is due to both the influence of waters of southern origin and to the shift in the northern end-member to more radiogenic values. These results and the comparison with local data in the area (Gutjahr et al., 2008) suggest that: 1) strong MOC is needed to bring radiogenic waters to formation site of northern end-member, 2) LGMc circulation with prominent AABW that fills the basin at bottom depths is the only plausible scenario to simulate the observed deep value.

Sediment focusing may be important in dictating the interpretation of Gutjahr et al. (2008) and these authors suggest that acquiring complementary data is essential. Our study also illustrates the necessity for additional depth profile measurements of $\varepsilon_{\mathrm{Nd}}$ at LGM in the western part of the Atlantic basin, where AABW preferentially flows. Such observations would allow a clear statement about the signature of the NADW/GNAIW change. Deep water measurements would also provide a information concerning the penetration of AABW into the basin, as it is expected to flow northward as far as $60^{\circ} \mathrm{N}$ (Curry and Oppo, 2005). Indeed, this area is more representative of the water mass influences in the basin, with a $\varepsilon_{\mathrm{Nd}}$ gradient directly dependent on the end-members contributions. The signature of bottom waters in LGMa is representative of the northern end-member $\left(\varepsilon_{\mathrm{Nd}}=-9.8\right)$, whereas southern component signature $\left(\varepsilon_{\mathrm{Nd}}=-7.6\right)$ can be observed in simulation LGMc (Table 1).

\section{Conclusions}

Using a simple parameterisation to model $\varepsilon_{\mathrm{Nd}}$ distribution in an OGCM, we have studied the impact of changes in the overturning cell and circulation patterns between LGM and Holocene on $\varepsilon_{\mathrm{Nd}}$ in the Atlantic basin.

The modernM simulation (LGM land-sea mask with modern forcing) shows that the presence of ice sheets, without significant variation in circulation, affects the $\varepsilon_{\mathrm{Nd}}$ of the Atlantic basin, and generates shifts in the composition of the end-members leading to a change in the mean $\varepsilon_{\mathrm{Nd}}$ of +0.4 units. In particular, the northern end member does 
not acquire its modern negative signature, due to restricted exchange with highly negative margins that are protected by ice sheets at the LGM. On the other hand, the southern end-member is not significantly affected by the change in bathymetry.

Water mass structures in the Atlantic basin are qualitatively similar in terms of $\varepsilon_{\mathrm{Nd}}$ distribution for the three LGM simulations, even though the circulation changes drastically from one to another. However, qualitatively, we note important changes in the $\varepsilon_{\mathrm{Nd}}$ of bottom waters in the western basin, which are consistent with a stronger penetration of southern water mass and the relative influence of components. As for modernM, the mean $\varepsilon_{\mathrm{Nd}}$ is 0.5 more radiogenic than during the modern run, suggesting that although circulation changes do not play a key role in end-members $\varepsilon_{\mathrm{Nd}}$ acquisition, they are important in redistributing the characteristics of the basin.

Very few data concerning $\varepsilon_{\mathrm{Nd}}$ at LGM are presently available. The change in isotopic composition between present and LGM observed in the data provided by Piotrowski et al. (2004) is partially reproduced by the model in all the oceanic circulation configurations. However, the location of the core is not the most relevant place for a comparison appraisal of the model, since the very complex local bathymetry and ocean dynamics complicate any comparison with our coarse resolution model. On the other hand, the LGMc simulation yields the most conclusive model-data comparison for bottom water in the western part of the basin (Gutjahr et al., 2008), but requires a greater influence of southern radiogenic waters to the northern end-member formation area (associated with a stronger MOC, like in LGMa scenario). We propose here that the north of the western part of the basin, where the composition of the end-members can easily be constrained, and where the only factor controlling the distribution of $\varepsilon_{\mathrm{Nd}}$ is the relative influence of the northern and southern components, would be a relevant site for future model/data comparison. This would also confirm/infirm the interpretation of the data of Gutjahr et al. (2008).

Substantial progress must be made in:

1. Understanding the modern $\mathrm{Nd}$ oceanic cycle, so as to better reproduce the features that drive the temporal evolution in the $\varepsilon_{\mathrm{Nd}}$.

2. Modeling of the LGM ocean circulation, since simulation LGMc was produced via the artificial addition of freshwater, and modeling of the other scenarios suggested by other studies (for example scenarios 2) and 3 ) mentioned in the introduction, which we have not tested because they have not yet been reproduced by OAGCMs).

3. Obtaining more data for $\mathrm{Nd}$ isotopes in order that $\mathrm{Nd}$ can be a consistent tool for intercomparison with other paleo proxies.
Acknowledgements. The authors would like to thank F. Peeters, M. Siddall, D. Vance and an anonymous referee for their comments that significantly improve the quality of the paper. A. Tagliabue is thanked for his linguistic advice. The LGM simulations have been obtained in the framework of the MOTIF (European Project EVK2-CT-2002-00153) and PMIP2 (http://pmip2.1sce.ipsl.fr) projects and in the ANR BLANC project IDEGLACE (ANR-05BLAN-0310-01, 2006-2009).

Edited by: F. Peeters

\section{References}

Abouchami, W., Galer, S. J. G., and Koschinsky, A.: Pb and $\mathrm{Nd}$ isotopes in NE Atlantic Fe-Mn crusts : Proxies for trace metal paleosources and paleocean circulation, Geochim. Cosmochim. Ac., 63, 1489-1505, 1999.

Albarede, F., Goldstein, S. L., and Dautel, D.: The neodymium isotopic composition in Mn nodules from the Southern and Indian Oceans, the global oceanic neodymium budget and their bearing on deep ocean circulation, Geochim. Cosmochim. Ac, 61, 12771291, 1997.

Alkama, R., Kageyama, M., and Ramstein, G.: Freshwater discharges in a simulation of the Last Glacial Maximum climate using improved river routing, Geophys. Res. Lett., 33, L21709, doi:10.1029/2006GL027746, 2006

Alkama, R., Kageyama, M., Ramstein, G., and Marti, O.: Impact of a realistic river routing in coupled ocean-atmosphere simulations of the Last Glacial Maximum climate, Clim. Dynam., 30, 855869,2008

Amakawa, H., Nozaki, Y., Alibo, D. S., Zhang, J., Fukugawa, K. and Nagai, H.: Neodymium isotopic variations in Northwest Pacific waters, Geochim. Cosmochim. Ac., 68, 715-727, 2004.

Arsouze, T., Dutay, J. C., Lacan, F., and Jeandel, C.: Modeling the neodymium isotopic composition with a global ocean circulation model, Chem. Geol., 239, 165-177, 2007.

Bayon, G., German, C. R., Boella, R. M., Milton, J. A., Taylor, R. N., and Nesbitt, R. W.: An improved method for extracting marine sediment fractions and its application to $\mathrm{Sr}$ and $\mathrm{Nd}$ isotopic analysis, Chem. Geol., 187, 179-199, 2002.

Broecker, W. S. and Denton, G. H.: The role of ocean-atmosphere reorganizations in glacial cycles, Geochim. Cosmochim. Ac., 53 , 2465-2501, 1989.

Broecker, W. S.: Constraints on the glacial operation of the Atlantic Ocean's conveyor circulation, Israel J. Chem., 42, 1-14, 2002.

Charles, C. D. and Fairbanks, R. G.: Evidence from Southern Ocean sediments for the effect of North Atlantic deep-water flux on climate, Nature, 355, 416-419, 1992.

Curry, W. B. and Lohmann, G. P.: Reduced advection into Atlantic Ocean deep eastern basins during last glaciation maximum, Nature, 306, 577-580, 1983.

Curry, W. B. and Oppo, D. W.: Glacial water mass geometry and the distribution of delta C-13 of Sigma $\mathrm{CO}_{2}$ in the western Atlantic Ocean, Paleoceanography, 20, PA1017, doi:10.1029/2004PA001021, 2005.

Duplessy, J. C., Shackleton, N. J., Fairbanks, R. G., Labeyrie, L., Oppo, D., and Kallel, N.: Deep water source variations during the last climatic cycle and their impact on the global deep water circulation, Paleoceanography, 3, 343-360, 1988. 
Dutay, J. C., Bullister, J. L., Doney, S. C., Orr, J. C., Najjar, R., Caldeira, K., Campin, J. M., Drange, H., Follows, M., Gao, Y., Gruberi, N., Hecht, M. W., Ishida, A., Joos, F., Lindsay, K., Madec, G., Maier-Reimer, E., Marshall, J. C., Matear, R. J., Monfray, P., Mouchet, A., Plattner, G.-K., Sarmiento, J., Schlitzer, R., Slater, R., Totterdell, I. J., Weirig, M.-F., Yamanaka, Y., and Yool, A.: Evaluation of ocean model ventilation with CFC-11: comparison of 13 global ocean models, Ocean. model., 4, 89-120, 2002.

Elderfield, H., Hawkesworth, C. J., Greaves, M. J., and Calvert, S. E.: Rare earth element geochemistry of oceanic ferromanganese nodules and associated sediments, Geochim. Cosmochim. Ac., 29, 209-220, 1981.

Fichefet, T. and Maqueda, M. A. M.: Sensitivity of a global sea ice model to the treatment of ice thermodynamics and dynamics, J. Geophys. Res.-Oceans, 102, 12 609-12 646, 1997.

Foster, G. L., Vance, D., and Prytulak, J.: No change in the neodymium isotope composition of deep water exported from the North Atlantic on glacial-interglacial time scales, Geology, 35, 37-40, 2007.

Franzese, A. M., Hemming, S. R., Goldstein, S. L., and Anderson, R. F.: Reduced Agulhas Leakage during the Last Glacial Maximum inferred from an integrated provenance and flux study, Earth Planet. Sc. Lett., 250, 72-88, 2006.

Ganopolski, A., Rahmstorf, S., Petoukhov, V., and Claussen, M.: Simulation of modern and glacial climates with a coupled global model of intermediate complexity, Nature, 391, 351-356, 1998.

Gherardi, J. M., Labeyrie, L., McManus, J. F., Francois, R., Skinner, L. C., and Cortijo, E.: Evidence from the Northeastern Atlantic basin for variability in the rate of the meridional overturning circulation through the last deglaciation, Earth Planet. Sc. Lett., 240, 710-723, 2005.

Goldstein, S. L. and Hemming, S. R.: Long lived Isotopic Tracers in Oceanography, Paleoceanography, and Ice sheet dynamics, in: Treatise on Geochemistry, edited by: Elderfield, H., Elsevier Pergamon press, Amsterdam, chapter 6.17, 2003.

Goosse, H. and Fichefet, T.: Importance of ice-ocean interactions for the global ocean circulation: A model study, J. Geophys. Res.-Oceans, 104, 23 337-23 355, 1999.

Gutjahr, M., Frank, M., Stirling, C. H., Keigwin, L. D., and Halliday, A. N.: Tracing the Nd isotope evolution of North Atlantic deep and intermediate waters in the Western North Atlantic since the Last Glacial Maximum from Blake Ridge sediments, Earth Planet. Sc. Lett., 266, 61-77, 2008.

Henderson, G. M., Heinze, C., Anderson, R. F., and Winguth, A. M. E.: Global distribution of the Th-230 flux to ocean sediments constrained by GCM modelling, Deep-Sea Res. Pt. I, 46, 18611893, 1999.

Hourdin, F., Musat, I., Bony, S., Braconnot, P., Codron, F., Dufresne, J. L., Fairhead, L., Filiberti, M. A., Friedlingstein, P., Grandpeix, J. Y., Krinner, G., Levan, P., Li, Z. X., and Lott, F.: The LMDZ4 general circulation model: climate performance and sensitivity to parametrized physics with emphasis on tropical convection, Clim. Dynam., 27, 787-813, 2006.

Jacobsen, S. B. and Wasserburg, G. J.: Sm-Nd isotopic evolution of chondrites, Earth Planet. Sc. Lett., 50, 139-155, 1980.

Jeandel, C.: Concentration and isotopic composition of $\mathrm{Nd}$ in the South Atlantic Ocean, Earth Planet. Sc. Lett., 117, 581-591, 1993.
Jeandel, C., Thouron, D., and Fieux, M.: Concentrations and Isotopic compositions of $\mathrm{Nd}$ in the Eastern Indian Ocean and Indonesian Straits, Geochim. Cosmochim. Ac., 62, 2597-2607, 1998.

Jeandel, C., Arsouze, T., Lacan, F., Techine, P., and Dutay, J. C.: Isotopic $\mathrm{Nd}$ compositions and concentrations of the lithogenic inputs into the ocean: A compilation, with an emphasis on the margins, Chem. Geol., 239, 156-164, 2007.

Keigwin, L. D. and Schlegel, M. A.: Ocean ventilation and sedimentation since the glacial maximum at $3 \mathrm{~km}$ in the western North Atlantic, Geochem. Geophy. Geosy., 3, 1034, doi:10.1029/2001GC000283, 2002.

Keigwin, L. D.: Radiocarbon and stable isotope constraints on Last Glacial Maximum and Younger Dryas ventilation in the western North Atlantic, Paleoceanography, 19, PA4012, doi:10.1029/2004PA001029, 2004.

Krinner, G., Viovy, N., de Noblet-Ducoudre, N., Ogee, J., Polcher, J., Friedlingstein, P., Ciais, P., Sitch, S., and Prentice, I. C.: A dynamic global vegetation model for studies of the coupled atmosphere-biosphere system. Global Biogeochem. Cy., 19, GB1015, doi:10.1029/2003GB002199, 2005.

Lacan, F. and Jeandel, C.: Neodymium isotopic composition and rare earth element concentrations in the deep and intermediate Nordic Seas: constraints on the Iceland Scotland Overflow Water signature, Geochem. Geophy. Geosy., 5, Q11006, doi:10.1029/2004GC000742, 2004.

Lacan, F. and Jeandel, C.: Acquisition of the neodymium isotopic composition of the North Atlantic Deep Water, Geochem. Geophy. Geosy., 6, Q12008, doi:10.1029/2005GC000956, 2005 a.

Lacan, F. and Jeandel, C.: Neodymium isotopes as a new tool for quantifying exchange fluxes at the continent - ocean interface, Earth Planet. Sc. Lett., 232, 245-257, 2005b.

Lévy, M., Aumont, O., Kremeur, A. S., Memery, L., and Ethé, C.: NEMO reference manual, tracer component: NEMO-TOP, Preliminary version, Note du Pole de modélisation, Institut PierreSimon Laplace (IPSL), 28, 2006.

Lynch-Stieglitz, J., Curry, W. B. and Slowey, N.: Weaker Gulf Stream in the Florida straits during the last glacial maximum, Nature, 402, 644-648, 1999.

Lynch-Stieglitz, J., Curry, W. B., Oppo, D. W., Ninneman, U. S., Charles, C. D., and Munson, J.: Meridional overturning circulation in the South Atlantic at the last glacial maximum, Geochem. Geophy. Geosy., 7, Q10N03, doi:10.1029/2005GC001226, 2006.

Lynch-Stieglitz, J., Adkins, J. F., Curry, W. B., Dokken, T., Hall, I. R., Herguera, J. C., Hirschi, J. J. M., Ivanova, E. V., Kissel, C., Marchal, O., Marchitto, T. M., McCave, I. N., McManus, J. F., Mulitza, S., Ninnemann, U., Peeters, F., Yu, E. F., and Zahn, R.: Atlantic meridional overturning circulation during the Last Glacial Maximum, Science, 316, 66-69, 2007.

Madec, G.: NEMO reference manual, ocean dynamics component: NEMO-OPA. Preliminary version, Note du Pole de modélisation, Institut Pierre-Simon Laplace (IPSL), 27, 2006.

Marchal, O., Francois, R., Stocker, F., and Fortunat, J.: Ocean thermohaline circulation and sedimentary ${ }^{231} \mathrm{~Pa} /{ }^{230} \mathrm{Th}$ ratio, Paleoceanography, 15, 625-641, 2000.

Marchitto, T. M. and Broecker, W. S.: Deep water mass geometry in the glacial Atlantic Ocean: A review of constraints from the paleonutrient proxy Cd/Ca, Geochem. Geophy. Geosy., 7, Q12003, doi:10.1029/2006GC001323, 2006. 
Marti, O., Braconnot, P., Bellier, J., Benshila, R., Bony, S., Brockmann, P., Cadule, P., Caubel, A., Denvil, S., Dufresne, J.-L., Fairhead, L., Filiberti, M.-A., Foujols, M.-A., Fichefet, T., Friedlingstein, P., Goosse, H., Grandpeix, J.-Y., Hourdin, F., Krinner, G., Lévy, C., Madec, G., Musat, I., de Noblet, N., Polcher, J., and Talandier, C.: The new IPSL climate system model: IPSL-CM4, Note du Pôle de Modélisation 26, 2006.

McManus, J. F., Francois, R., Gherardi, J.-M., Keigwin, L. D., and Brown-Leger, S.: Collapse and rapid resumption of Atlantic meridional circulation linked to deglacial climate changes, Nature, 428, 834-837, 2004.

Oppo, D. and Fairbanks, R. G.: Variability in the Deep and Intermediate Water Circulation of the Atlantic Ocean During the Past 25,000 Years: Northern Hemisphere Modulation of the Southern Ocean, Earth Planet. Sc. Lett., 86, 1-15, 1987.

Oppo, D. and Rosenthal, Y.: Cd/Ca changes in a deep Cape Basin core over the past 730000 years: Response of circumpolar deepwater variability to northern hemisphere ice sheet melting?, Paleoceanography, 9, 661-676, 1994.

Peltier, W. R.: Global glacial isostasy and the surface of the ice-age earth: The ICE-5G (VM2) Model and GRACE, Annu. Rev. Earth Pl. Sc., 32, 111-149, 2004.

Piepgras, D. J. and Wasserburg, G. J.: Neodymium isotopic variations in seawater, Earth Planet. Sc. Lett., 50, 128-138, 1980.

Piepgras, D. J. and Wasserburg, G. J.: Isotopic composition of neodymium in waters from the Drake Passage, Science, 217, 207-217, 1982.

Piepgras, D. J. and Wasserburg, G. J.: Influence of the Mediterranean outflow on the isotopic composition of neodymium in waters of the North Atlantic, J. Geophys. Res., 88, 5997-6006, 1983.

Piepgras, D. J. and Wasserburg, G. J.: Rare earth element transport in the western North Atlantic inferred from isotopic observations, Geochim. Cosmochim. Ac., 51, 1257-1271, 1987.

Piotrowski, A. M., Goldstein, S. L., Hemming, S. R., and Fairbanks, R. G.: Intensification and variability of ocean thermohaline circulation through the last deglaciation, Earth Planet. Sc. Lett., 225, 205-220, 2004.

Rahmstorf, S.: Ocean circulation and climate during the past 120000 years, Nature, 419, 207-214, 2002.
Reynolds, B. C., Sherlock, S. C., Kelley, S. P., and Burton, K. W.: Radiogenic isotope records of Quaternary glaciations: Changes in the erosional source and weathering processes, Geology, 32, 861-864, 2004.

Rutberg, R. L., Hemming, S. R., and Goldstein, S. L.: Reduced North Atlantic deep Water flux to the glacial Southern Ocean inferred from neodymium isotope ratios, Nature, 405, 935-938, 2000.

Spivack, A. J. and Wasserburg, G. J.: Neodymium isotopic composition of the Mediterranean outflow and the eastern North Atlantic, Geochim. Cosmochim. Ac.; Vol/Issue: 52:12, Pages: 2767-2773, 1988.

Swingedouw, D., Braconnot, P., Delecluse, P., Guilyardi, E., and Marti, O.: The impact of global freshwater forcing on the thermohaline circulation: adjustment of North Atlantic convection sites in a CGCM, Clim. Dynam., 28, 291-305, 2007.

Tachikawa, K., Athias, V., and Jeandel, C.: Neodymium budget in the ocean and paleoceanographic implications, J. Geophys. Res., 108(C8), 3254, 2003.

Valcke, S.: OASIS3 User Guide (prism_2-5), PRISM Support Initiative Report, 3, 64, 2006.

Van De Flierdt, T., Frank, M., Lee, D. C., Halliday, A. N., Reynolds, B. C., and Hein, J. R.: New constraints on the sources and behavior of neodymium and hafnium in seawater from Pacific Ocean ferromanganese crusts, Geochim. Cosmochim. Ac., 68, 38273843, 2004.

van de Flierdt, T., Robinson, L. F., Adkins, J. F., Hemming, S. R., and Goldstein, S. L.: Temporal stability of the neodymium isotope signature of the Holocene to glacial North Atlantic, Paleoceanography, 21, PA4102, doi:10.1029/2006PA001294, 2006.

Vance, D. and Burton, K.: Neodymium isotopes in planktonic foraminifera: A record of the response of continental weathering and ocean circulation rates to climate change, Earth Planet. Sc. Lett., 173, 365-379, 1999.

von Blanckenburg, F.: Perspectives: Paleoceanography - Tracing past ocean circulation?, Science, 286, 1862-1863, 1999.

Yu, E.-F., Francois, R., and Bacon, M.: Similar rates of modern and last-glacial ocean thermohaline circulation inferred from radiochemical data, Nature, 379, 679-680, 1996. 